ДЕРЖАВНЕ РЕГУЛЮВАННЯ НАУКОВОЇ ДІЯЛЬНОСТІ:
ЗАРУБІЖНИЙ ДОСВІД ТА МОЖЛИВОСТІ ДЛЯ УКРАЇНИ

\title{
STATE REGULATION OF SCIENTIFIC ACTIVITY: FOREIGN EXPERIENCE AND OPPORTUNITIES FOR UKRAINE
}

\begin{abstract}
Закордонний досвід регулювання державою наукової галузі для України є важливим, оскільки саме через його застосування наша держава може отримати статус держави з високим науковим потенціалом. Часткова імплементація положень чинного законодавства передових країн дозволить сфрормувати раціональний $i$ належний механізм державного регулювання наукової галузі для нашої держави на сучасному етапі. Таке питання є особливо актуальним для України, оскільки наукова діяльність є потужним інструментом для розвитку економіки та виходу країни із кризи. Водночас виникає потреба адаптаціі державної політики в галузі науки до умов глобалізації, що надалі зумовлює перегляд основоположних принципів, методів та механізмів розроблення і здійснення державного регулювання окресленої галузі. Автор уважає, що використання зарубіжного досвіду державного регулювання галузі науки в Україні може допомогти у вирішенні дано проблеми. у статmі досліджено досвід регулювання наукової діяльності низки європейських країн (Федеративна Республіка Німеччина, Великобританія, Франція, Швеція та Фінляндія), Сполучених Штатів Америки, Японії та Китаю. У роботі проаналізовано напрями і механізми державного регулювання науки в іноземних країнах. Вивчення закордонного досвіду державного регулювання наукової діяльності дозволило з'ясувати наявність відмінностей такого регулювання в різних країнах світу. установлено роль технологічних парків та міст-технополісів у поступі світового науково-технічного прогресу. Загальною тенденцією світового науково-технічного прогресу є створення і розвиток технологічних, наукових парків та будівництво цілих міст - наукових технополісів. Визначено, що немає універсальних інструментів стимулювання розвитку наукової діяльності, кожна держава використовує своі власні методи. Обірунтовано доцільність використання окремих інструментів в українських умовах.
\end{abstract}

к. іст. наук,

завідувач кафедри документознавства та інсрормаційної діяльності ПВНЗ «Академія рекреаційних технологій і права»
Ключові слова: державне регулювання, наукова діяльність, наукова установа, джерела фрінансування, зарубіжний досвід, дослідження.

Foreign experience of government control of scientific sphere for Ukraine is very important, so as exactly by means of Ukraine can purchase status of country with high scientific potential. Due to partial implementation of norms of current legislation of the developed foreign countries to work out the rational mechanism of government control of scientific sphere for our country on the modern stage. This issue is especially actual for Ukraine, because scientific activity is a powerful tool for economic development and the country's exit from the crisis. At the same time there is necessity of adaption of public policy in the field of scientific to the terms of globalization, that it in turn envisages the cardinal revision of principles, methods and mechanisms of making of public policy in the field of it. Author considers that borrowing of foreign experience of government control of scientific sphere can bring to the decision of this range of problems. The article deals with research on the regulation of the scientific activities of European countries (FRG, Great Britain, France, Sweden and Finland), the United States of America, Japan and China. In the article the directions and mechanisms of state regulation of science in foreign countries are analyzed. Studying the foreign experience of public regulation of scientific activity made it possible to find out the differences of such regulation in different countries of the world. The role of Technological parks and city-technopolises in the development of world scientific and technological progress has been established. The general trend of world scientific and technological progress is the creation and development of technological, scientific parks and the construction of entire cities-scientific technopolis. We found that there are no universal incentive tools; each country uses its own methods. The expediency of using separate instruments in the Ukrainian conditions.

Key words: state regulation, scientific activity, scientific institution, sources of funding, foreign experience, research.
Постановка проблеми в загальному вигляді. Для реалізації політики в науковій галузі державою застосовуються різноманітні способи та методи регулювання даної сфери. Наша держава нині перебуває на шляху інтегрування в європейський простір, зокрема й науковий, що зумовлює необхідність упорядкування саме організаційно-правових основ здійснення наукової діяльності у країні, механізмів державного регулювання наукової галузі. Вивчення й імплементація кращих закордонних практик у вітчизняний механізм регулювання державою наукової діяльності
$€$ одним із напрямів для його поліпшення, а також малодослідженим аспектом на сучасному етапі.

Аналіз останніх досліджень і публікацій. Науковці та практики дедалі більше цікавляться закордонним досвідом управління наукою. Зокрема, це питання досліджувалося В. Будкіним [1], Л. Водянкою [2], І. Даниловою [3], Р. Кропивницьким [4; 5], Т. Луценко [6], О. Ядранською й іншими.

Мета статті - зробити аналіз зарубіжного досвіду державного регулювання сфери науки та можливості його застосування в 
українських реаліях для розвитку наукової галузі загалом.

Виклад основного матеріалу. Українська держава на сучасному етапі володіє високим науковим потенціалом. Для його розвитку держава повинна створювати умови ефективного функціонування наукової галузі, що чинитиме позитивний вплив на розвиток усіх суспільних галузей. Проте в науково-технічній галузі України помітно низку негативних тенденцій (старіння кадрів, зношеність матеріально-технічної бази тощо), що нині загалом ставить нашу державу на один рівень із країнами третього світу в розвитку в науковому вимірі. Дослідниками нині виокремлено причини наявності в українській науковій галузі проблем, серед яких: недосконалість нормативно-правової бази в даній сфері, що чинить негативний вплив на всі напрями здійснення наукової роботи в Україні; нечіткість правових основ державної політики щодо існування ринку наукових технологій, здійснення інноваційної діяльності, комерціалізації науково-дослідних та науково-технічних розробок; відсутність системності у визначенні пріоритетних наукових галузей стратегічного значення для держави; слабка державна інвестиційна та фінансова політика в галузі; неналежний рівень розвитку міжнародної наукової співпраці тощо. Для вирішення цих та багатьох інших проблем насамперед варто створити дієвий механізм реалізації всіх поставлених перед державою та соціумом завдань. Для цього треба не лише виокремити та комплексно вивчити низку проблем у науковій галузі, а й надати експертні рекомендації щодо покращення ситуації в українській науці. Одним із напрямів може стати саме міжнародний досвід регулювання державою наукової діяльності (насамперед - особливості реформування науки у провідних країнах світу) та можливості його імплементації в Україні [3, с. 80].

У більшості країн світу, для яких характерний високий рівень поступу наукової галузі, спостерігається впровадження низки схожих інструментів в управлінні науковою діяльністю. Так, нині й надалі застосовується системний підхід до провадження інноваційної політики провідними державами, комплексні програми стимулювання науково-інноваційної діяльності, модернізації науково-дослідної та науково-конструкторської галузей, збільшення фінансування приватним сектором досліджень, зростання співпраці приватних, державних та бізнес-структур під час реалізації загальнодержавних наукових програм (зазначені недержавні інституції також усе більше долучаються до розроблення відповідного законодавства й ухвалення важливих рішень для поступу галузі) [6, с. 312].

Відзначимо, що загалом виокремлюють різні типи регулювання галузі державою - централізований, децентралізований і проміжний [3, с. 80]. До останнього належать системи управління Великої Британії та Німеччини. Характерною рисою управління наукою у Федеративній Республіці Німеччина (далі - ФРН) є поділ управлінських функцій між федеральним та земельними урядами, тобто має місце загальнодержавний та регіональний аспекти керівництва галуззю. На вищому рівні управління науковою й інноваційною сферою здійснюють в основному Міністерство освіти і науки та Міністерство економіки і праці, а також частково (через фінансування й іншу підтримку стратегічно важливих галузевих наукових програм) - інші міністерства. Причому саме грошові надходження на науково-дослідну діяльність походять із трьох джерел: федерального, місцевих та спільно з обох бюджетів. Державне фінансування спрямовується насамперед на фундаментальні наукові дослідження. Особливістю німецького регулювання галуззю є наявність фінансування з регіональних бюджетів, а також значна частка грошових надходжень на наукові дослідження від недержавних установ, фондів тощо [4, с. 136]. Як бачимо, підтримка наукової діяльності у ФРН здійснюється не лише на вищому державному рівні, а й на місцевому, що не характерно для української держави. Тому в нашій країні можна було б використати цей позитивний німецький досвід у напрямі регіональної/ місцевої підтримки наукових установ та ініціатив [7, с. 47].

Як Німеччина, так і Великобританія є визнаними країнами з високим науковим потенціалом і ефективним регулюванням наукової галузі. У цій країні наукові розвідки здійснюються у трьох напрямах: державному (Фундаментальні та прикладні дослідження), освітянському (виші зосереджені на фундаментальних розробках) та приватному (здебільшого прикладні дослідження для їх комерціалізації та подальшого впровадження у виробництво). Так, частка закладів саме приватного сектору в науковій роботі є чи не найбільшою у країні (приблизно 85\%). Усе ж державна підтримка галузі $є$ значною, адже в підсумку забезпечує належний та стабільний розвиток наукової галузі країни. Для цього застосовуються фінансові й управлінські засоби і методи. На найвищому рівні впроваджуються заходи для залучення науковців та фахівців з інших держав (зокрема, для підготовки молодих наукових кадрів), підтриму- 
ються довготривалі науково-дослідні проєкти тощо [5, с. 136]. Британська політика у сфері науки характеризується довгостроковістю, що пояснюється необхідністю тривалого терміну як для підготовки молодих наукових кадрів, так і для практичного впровадження відкриттів чи науково-дослідних розробок [3, с. 82].

у Франції за наукову роботу відповідають відповідні профільні міністерства наукових досліджень (у складі Міністерства освіти і науки) та промислового зростання (у складі Міністерства економіки, фінансів та промисловості). Решта міністерств лише частково причетні до наукових досліджень. Регулювання державою галузі здійснюється через фінансові важелі, а саме прямі (безвідсоткові позики) та непрямі (податкові знижки та канікули) [5, с. 144]. Для нашої держави французький досвід буде корисним у сфері збільшення прав наукових установ та вишів, а саме під час перерозподілу державних асигнувань у самій інституції; зростання частки здійснення вченими власне наукової роботи за зменшення водночас адміністративно-бюрократичних процедур [3, с. 81].

У Швеції наукова діяльність у вишах фінансується насамперед із коштів державного бюджету. Загалом грошові ресурси спрямовуються на наукові розробки переважно промисловим сектором. У цій країні $є$ низка державних структур (Шведська рада з наукових досліджень, Шведське управління з інноваційних систем тощо), які в основному і здійснюють організаційне та фінансове регулювання наукової діяльності. Інші ж інституції мають невеликий вплив на поступ наукової галузі Швеції. Ще однією відмінністю шведського досвіду $є$ наявність статусу науково-дослідних в усіх університетах країни, а також пільгової системи для вишів, яка на державному рівні ствердила вишівську науково-досліду та фінансову автономію (2010 р.) [4, с. 137].

Відмінним $є$ фінський досвід керівництва науковою галуззю, що здійснює низка державних інституцій. Так, урядова Рада з науково-технологічної політики в основному відповідає за стимулювання економічного поступу через впровадження новітніх розробок у промисловість та інші галузі. Агентство з фінансування технологій та інновацій (Tekes) здійснює планування, розподіл та моніторинг використання бюджетних коштів. Національний фонд із питань досліджень і розвитку (Sitra) є незалежною державною інституцією та здійснює інвестування у прогресивні науково-технологічні проєкти [5, с. 145].

Саме окреслені вище три країни - Франція, Швеція та Фінляндія - є прикладами ефек- тивного державного регулювання централізованого типу в науковій галузі [3, с. 81]. Європейська модель має низку особливостей (частково сюди можна віднести і Японію), як-от: активне втручання в наукову й інноваційну галузі; частка наукових та науково-конструкторських розробок була здійснена внаслідок виконання спільних проєктів та програм у рамках Європейського Союзу, а не окремими державами, що загалом має позитивне значення для концентрації матеріальних та людських ресурсів, вирішення найбільш важливих науково-дослідних завдань [1, с. 27].

Р. Кропивницький уважає, що більшій частині країн Євросоюзу, які характеризуються динамічним розвитком та результативністю наукової галузі, притаманна низка подібних рис, серед яких значна частка фінансування досліджень із державного бюджету. Попри прогресивність даного досвіду для нашої держави, усе ж він не позбавлений негативних рис: бюрократизм, інертність та закритість від новацій системи науково-дослідної роботи; непривабливість наукової діяльності як такої, отже, і бажання робити кар'єру науковця тощо [4, с. 137].

Одним із представників децентралізованого типу ефективного керівництва сьогодні $€$ США. Профільного міністерства з питань наукової діяльності в державі немає, проте є низка інших інституцій, які здійснюють дослідження за відповідними напрямами: державні департаменти з питань охорони здоров'я, енергетики, оборони, сільського господарства тощо. Під час перерозподілу фінансування між відповідними організаціями діє правило конкурсного відбору проєктів та програм за напрямами. Характерною рисою є також періодичне ствердження окремих програм галузевого розвитку на законодавчому рівні, тобто які мають силу закону в державі. Зазвичай такі програми спрямовані на вирішення загальнонаціональних стратегічних завдань, які постають перед країною у науковій чи суміжній галузях. Ще одна відмітна риса американської моделі - це існування системи вищої освіти включно зі значною часткою здійснення наукових досліджень у вишах. Водночас освітня система орієнтована на ринок і здійснює підготовку кадрів і актуальні наукові дослідження згідно з його потребами. Така взаємодія наукової галузі та корпоративного сектору й дотепер робить наукову діяльність у США однією з найбільш ефективних та привабливих для фахівців з усього світу [5, с. 150]. Водночас ефективною є й система оцінювання результатів практичної реалізації державної політики в науковій сфері, насамперед через такі форми, як експертиза, пілотні наукові розвідки тощо. 
Причому у США власне оцінювання здійснюється не для обґрунтування надання фінансових асигнувань на проєкт чи програму, а для аналізу досягнутого рівня виконаних робіт згідно з тими же проєктами чи програмами, подальшого коригування державної політики у сфері здійснення наукової діяльності [3, с. 83]. у Сполучених Штатах Америки, а також Канаді втручання держави є опосередкованим, адже вона організовує суто організаційно-правові умови для здійснення наукової й інноваційної діяльності, проте пряма фінансова підтримка в напрямі реалізації такої діяльності не здійснюється [1, с. 27].

У Японії найбільш важливі рішення з питань науки та взаємообмін інформацією між науковцями, державою та бізнес-структурами здійснює так звана Наукова рада, яка є профільним агентством під керівництвом прем'єр-міністра Японії. Також функціонує некомерційна інституція - Японське товариство сприяння розвитку науки (JSPS) як незалежна організація для просування науки в різних суспільних галузях, підтримки молодих учених, міжнародної співпраці тощо. На діяльність останньої щороку виділяються субсидії уряду [4, с. 138].

Однією із країн із швидким економічним поступом сьогодення $€$ Китай, досвід керівництва науковою галуззю якого є цікавим i для України. Фактично китайською державою науковим інституціям надано автономність та свободу, забезпечені прозорість та відкритість щодо надходжень до наукових закладів державного фінансування. До того ж останнє відбувається на конкурсній основі. У підсумку такі реалії сприяють зростанню продуктивності науково-дослідної роботи, конкурентоспроможності окремих інституцій і науковців. Ефективністю відзначається програма залучення фахівців із закордону [5, с. 150].

Для більшості прогресивних країн характерним є започаткування технологічних парків та наукових технополісів, а також інших форм інноваційно-наукової роботи (кластери, бізнес-школи тощо). Так, технологічні або наукові парки є спеціально створеною системою, яка упорядковує та спрямовує діяльність освітніх та науково-дослідних інституцій, надає низку послуг, які в підсумку сприяють зростанню добробуту країни. Часто за кордоном активно до розвитку технопарків залучаються освітні установи, застосовуються лабораторії й інфраструктура вишів тощо. Найвищим виявом взаємодії науки та виробництва є започаткування та розвиток наукових міст - технополісів. Характерними рисами останніх є зосередження та поєднання наукових досліджень із найбільш важливих напрямів із подальшим їх упровадженням у виробництво. Саме на території технополісів створюється відповідна інфраструктура, яка задовольняє інтереси науковців, працівників промислових підприємств та інших їхніх мешканців [2, с. 80].

У цьому контексті основна відмінність існування технопарків та технополісів в умовах централізованого та децентралізованого типів державного регулювання полягає у відповідно заснуванні або державою, або приватним коштом; також відповідно здійснюється й фінансування [1, с. 27].

Зважаючи на стан розвитку української наукової галузі та передовий досвід провідних країн світу, варто висловити такі рекомендації для поліпшення державного регулювання науковою діяльністю в Україні. Насамперед варто закласти основу державної політики в цій галузі, зокрема через затвердження відповідного документа-концепції. Теоретики та практики повинні спільно підготувати пропозиції стосовно покращення законодавчої бази в науковій галузі загалом. Окрім того, на державному рівні треба запровадити дієві заходи для підготовки наукових кадрів; розробити систему прогнозування розвитку галузі та здійснювати державну політику відповідно до вимог часу та змін національного чи загальносвітового характеру. На сучасному етапі Україна потребує державної підтримки та більшої участі недержавного сектору в напрямі розроблення та практичного впровадження інноваційної політики, що включає й гідне фінансування наукових проєктів та програм. Останній аспект потребує також створення належної системи контролю за використанням державних ресурсів під час їх розподілу, а також варто закласти організаційно-правову базу для стимулювання залучення до розроблення наукової політики, фінансування тощо інших суб'єктів, які можуть бути зацікавлені в поступі наукової сфери (недержавні організації, бізнес-структури, фонди тощо). Першочерговим для України має стати створення правових рамок не лише щодо розроблення, а і стосовно практичного впровадження наукових технологій. Задекларованим у чинному законодавстві так і залишається міжнародне співробітництво, яке варто активізувати у практичній площині. Невирішеною проблемою залишається «відтік мізків» за кордон, що зумовлює «старіння» наукових кадрів України та загалом негативно відображається на економічному поступі України. Вищеокреслені пропозиції варто впроваджувати поступово та комплексно, у співпраці державних органів влади, вищого та регіонального рівнів, та недержавних об'єднань. 
Висновки. Проаналізований вище закордонний досвід керівництва державою наукової діяльності свідчить про використання більшою мірою фінансових важелів управління, а саме прямих та непрямих фінансових асигнувань. Нині простежуються тенденції зростання фінансування наукових досліджень із боку недержавних установ, об'єднань, фірм тощо; розширення автономії та зменшення адміністративно-бюрократичного навантаження на науково-дослідні установи; створення систем оцінювання ефективності практичної реалізації політики держави в науковій сфері; започаткування науково-виробничих об'єднань у формі наукових чи технологічних парків, технополісів. Дана проблематика потребує подальших досліджень у напрямі доцільності застосування окремих важелів керівництва науковою галуззю в українських реаліях, які виявилися ефективними у провідних країнах світу.

\section{ЛITEPATУРA:}

1. Будкін В. Державна інноваційна політика: український та зарубіжний досвід. Дослідження міжнародної економіки. 2011. № 1 (66). С. 25-40.
2. Водянка Л., Підгірна В., Сироїжко К. Зарубіжний досвід державного регулювання інноваційної діяльності. Інвестиції: практика та досвід. 2018. № 9. С. 77-82.

3. Данилова I. Зарубіжний досвід державного регулювання наукової сфери : теоретико-методологічні рекомендації для України. Национальный юридический журнал: теория и практика. 2014. Грудень. С. 79-85.

4. Кропивницький Р. Державне регулювання та розвиток наукової діяльності: зарубіжний досвід та можливості для України. Інвестиції: практика та досвід. 2018. № 10. С. 135-140.

5. Кропивницький Р. Зарубіжний досвід державного регулювання науковою діяльністю. Державне управління. 2020. № 4 (6). С. 143-159.

6. Луценко Т. Міжнародний досвід державного регулювання науки та інноваційної діяльності. Теорія та практика державного управління. 2015. Вип. 2. C. 311-316.

7. Христинченко Н. Міжнародно-правовий аспект розвитку наукової діяльності в зарубіжних країнах. Актуальні проблеми правознавства. 2017. Вип. 2 (10). С. 46-50.

8. Ядранська О. Державне регулювання науки в Україні : авторефр. дис. ... канд. наук з держ. упр.: 25.00.02. Запоріжжя, 2009. 23 с. 